CATALAN REVIEW

Catalan Review

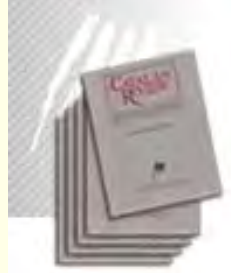

You are accessing the Digital Archive of the Catalan Review Journal.

By accessing and/or using this Digital Archive, you accept and agree to abide by the Terms and Conditions of Use available at http://www.nacs-

catalanstudies.org/catalan_review.html

Catalan Review is the premier international scholarly journal devoted to all aspects of Catalan culture. By Catalan culture is understood all manifestations of intellectual and artistic life produced in the Catalan language or in the geographical areas where Catalan is spoken. Catalan Review has been in publication since 1986 .
NORTH

AMERICAN

CATALAN

SOCIETY
Esteu accedint a l'Arxiu Digital del Catalan Review

A l' accedir i / o utilitzar aquest Arxiu Digital, vostè accepta i es compromet a complir els termes i condicions d'ús disponibles a http://www.nacs-

catalanstudies.org/catalan_review.html

Catalan Review és la primera revista internacional dedicada a tots els aspectes de la cultura catalana. Per la cultura catalana s'entén totes les manifestacions de la vida intel lectual i artística produïda en llengua catalana o en les zones geogràfiques on es parla català. Catalan Review es publica des de 1986.

\title{
The short narrative in medieval catalan literature Edward Neugaard
}

Catalan Review, Vol. V, number 2 (December, 1991), p. 89-95 


\section{THE SHORT NARRATIVE IN MEDIEVAL CATALAN LITERATURE}

\section{EDWARD NEUGAARD}

The short narrative in medieval Spanish literature has been the subject of considerable study on the part of Hispanists, who consider the genre as one of the most important of the period. John E. Keller, among others, has published numerous critical editions, monographs and articles on the various collections of Spanish folktales. Their counterpart in Catalan literature, however, have been largely ignored. Even the histories of Catalan literature done by Catalans, such as those of Molas, Riquer, Rubió, Ruiz i Calonja, etc. dedicate little space to the medieval folktales in Catalan. Although not quite as extensive as that written in Castilian, the short narrative in medieval Catalan literature does appear in a considerable number of works.

In the last century the first American professor of Spanish literature, Prof. George Ticknor of Harvard University, published several works on medieval Hispanic literature in general and on the short narrative in particular. His studies were soon followed by those of Ramón Menéndez Pidal and later by those of Marcelino Menéndez y Pelayo, whose Orígenes de la novela contained the first definitive study of the origins of short prose fiction. Recently Prof. María Jesús Lacarra published her Cuentística medieval en España: Los orígenes, in which she develops new theories regarding the origins of the genre in medieval Spain. In this work, however, only brief mention is made of the Catalan tales.

One of the most thorough studies of medieval Catalan prose fiction is contained in Felix Karlinger's Einführung in die romanische Volksliteratur, in which he dedicates an entire chapter to the genre. A more recent study of this literary type, the Formes narratives breves, written by John E. Keller and 
Albert Gier, again only mentions, in a rather cursory fashion, a few Catalan works.

To date, then, no complete inventory of all short prose fiction in Catalan of the Middle Ages has been made. The present study does not pretend to be either exhaustive nor definitive, but does include most of the works that could be classified as short narratives in medieval Catalan.

The majority of works that can be classified as short prose narratives also bear the name exempla. These terms are used practically interchangeably when refering to medieval short prose narratives, however many scholars prefer that the term exempla be employed only if there is a clearly intended moral lesson. If animals are the protagonists, such as in the Aesop's, tales, the terms "apologue» and ufable» are often substituted.

Most of the short prose narratives in Hispanic literature of the Middle Ages were imported into the Iberian Penninsula by the Arabs and were subsequently translated into Latin as well as into the Iberian vernacular languages. We know that the Castilian king Alfonso el Sabio had his own School of Translators who translated several of these works from Arabic into Latin as well as into Spanish. Scholars today agree that these narrative tales had their ultimate origins in ancient India. The majority were believed to have been translated first into Persian and then into Arabic.

One of the first collections of these stories that we have in Spain is the famous Disciplina clericalis, which was compiled by Pedro Alfonso de Huesca, a Jewish convert, and was subsequently translated into Spanish with the title El libro de los enxemplos por a.b.c. Other important collections of exempla in Spanish include the mysterious Barlaam y Josafat, which is generally believed to be a Christianized version of the Buddah legend; the Conde Lucanor of Don Juan Manuel; the Corbacho of the Archpriest of Talavera; the Libro de los qatos; the Libro de los engaños and the Calila y Dimna. These collections of folk tales represent the major corpus of short prose narratives in medieval Spanish literature. 
The corresponding collections of short prose narratives in medieval Catalan literature, as we have seen, are only briefly mentioned in histories of Catalan literature. For example the histories of Martí de Riquer and of Joaquim Molas only mention one work of this genre -the Recull de eximplis. This work, whose complete title is Recull de eximplis e miracles, gestes, $e$ faules ordenades per a.b.c., is, indeed, the most extensive collection of short prose narratives in Catalan. It was published by Marià Aguiló $i$ Fuster in two volumes -1872 and 1904 . It contains some 712 short prose narratives, or exempla. Aguiló was seemingly not awate that it is, in fact, a translation of the Latin Alphabetum Narrationem of Étienne de Besançon that was made in the I 5 th century. Most scholars believe that the Catalan translation, due to its linguistic pecularities, was actually made in the same century as its Latin model -the I sth century. It is, in reality, the largest collection of short prose narratives in a Hispanic language. The Libro de los exemplos por a.b.c., the most extensive collection in Spanish, contains only 556 tales.

The next largest collection of Catalan short narratives are those contained in the works of the Valencian writer Sant Vicent Ferrer. They have been published in three different collections: his Sermons, his Sermons de Quaresma and his Sermons valencians. Prof. Vicent Almazan has studied Ferrer's tales in great detail in his article "L'exemplum chez Vicent Ferrier». He lists some 183 exempla, of which 59 are Biblical in nature. These stories are dispersed throughout his sermons. Not all of his Sermons have been published and a large number of them were lost in the Spanish Civil War.

As in medieval Castilian literature, the Aesopic fables are also evident in Catalan. There are two separate collections of Aesop's fables translated into Catalan. One, consisting of some 97 tales, bears the title Faules isòpiques de Aviano, Alfonso, Poggio $i$ altres autors, and the other, the Faules d'Isop, consists of $8 \mathrm{I}$, The total number of tales in the two collections, then, is $I 78$. 
These were both published in 1908 and were based on 16 th century editions. Most likely they originated, however, in incunabula of the I5TH century.

Another collection of short prose narratives is the Libre de bones costumes dels hòmens e dels oficis dels nobles, translated in the I 5 th century from a Latin work. It contains some 65 narratives, mostly of Classic origin. The author was a certain Cessoles or Cessulis. It was published in 1902 by Manel Bofarull.

The next collection, according to its richness in short narratives, is the Flors de virtut e de costums. This is a Catalan translation of an original Italian work with the title Fiore di Virtù, attributed to a number of Italian writers of the time. The Catalan translation was done by Francesc de Santcliment, probably in 1489. It contains some 63 exempla.

Francesc Eiximenis was one of the most prolific writers of his time -after Ramon Llull the most prolific writer in Catalan. Marçal Olivar collected all the short narratives of Eiximenis' work and published them with the title Contes i faules. They total some 53 stories.

The miracles of the Virgin Mary represent one of the most widely cultivated genres of short prose narratives of the Middle Ages. In Spanish we have the Cantigas de Santa Maria, an extensive collection made by the Castilian king Alfonso el Sabio. A similar, but not nearly so extensive collection in Catalan bears the title the Miracles de la Verge Maria. It contains 36 narratives and was published in 1956 by Pere Bohigas.

Some of the works of the greatest Catalan writer, Ramon Llull, contain exempla. Within his novel Felix, there is intercalated a collection of fables called Llibre de les bèsties, which consists of 27 oriental type fables that involve animals as protagonists. The other short narratives which occur interspersed throughout his extensive writings have not yet been separated and studied. They undoubtedly represent a very substantial corpus of short narratives.

The Recull d'exemples morals, which exists in manuscript 
form in the Arxiu de la Corona d'Aragó in Barcelona, contains only seven short narratives in prose. It is a translation of a work done by a certain Fray Llorens and is often referred to by its various French titles: the Somme Lorens, the Somme des vices et de virtus and as the Miroir du monde. It contains only seven short narratives and is the smallest collection in Catalan.

In an article that appeared in the Revue des Langues Romanes Milà i Fontanals describes a Catalan version of the Disciplina clericalis that existed in the Biblioteca National at that time. This manuscript can no longer be found in the library.

The Biblioteca Colombina in Sevilla supposedly houses a Catalan version of the Barlaam and Josaphat legend, but it, too, apparently no longer exists.

These, then, are the principal collections of short prose fiction of Medieval Catalan Literature. The total number of short narratives as listed above comes to I,324. Prof. Keller has calculated the total number of medieval short narratives in Spanish as being 1,500 in number. With the short prose narratives in the Catalan works of Ramon Llull still not completely accounted for, it is possible that the total number in Catalan could come very close to the total for Spanish. It is a considerable body of literature and yet has barely been studied.

\author{
EDWARD J. NEUGAARD \\ UNIVERSITY OF SOUTH FLORIDA
}

\title{
WORKS CITED
}

Alfonso, Pedro. Disciplina clericalis. Ed. y trad. del texto latino Ángel González Palencia. Madrid: Consejo Superior de Investigaciones Científicas, 1948.

Almazan, Vicent, "L'Exemplum chez Vincent Ferrier». Romanische Forschungen 79 (1967), 288-332.

Barlaam y Josafat. Eds. John E. Keller and Robert W. Linker. 
Clásicos Hispánicos, 21. Madrid: Consejo Superior de Investigaciones Científicas, 1979 .

EIximenis, Francesc. Contes i faules. Ed. Marçal Olivar. Els

Nostres Clàssics, 6. Barcelona: Editorial Barcino, I925.

Les faules d'Isop. Ed. R. Miquel i Planas. Barcelona: Fidel Giró, I908.

Faules isòpigues de Aviano, Alfonso, Poggio y altres autors. Ed.

R. Miquel y Planas. Històries d'Altre Temps, 6. Barcelona:

Fidel Giró, 1908.

Ferrer, Sant Vicent. Sermons. 6 vols. Eds. Joseph Sanchis Sivera (I and II) and Gret Schib (III - VI). Barcelona: Editorial Barcino, 1932-I988.

- Sermons de Quaresma. 2 vols. Ed. M. Sanchis Guarner. Clàssics Albatros, 3-4. València: Clàssics Albatros, 1973.

- Sermons valencians. R. Chabàs. «Estudio sobre los sermones valencianos de San Vicente Ferrer que se conservan manucritos en la Biblioteca de la Basílica Metropolitana de Valencia.n Revista de Archivos, Bibliotecas y Museos 6 (I902), I-6 and I55-I68; 7 (I9O2), I3 I-I 42 and 4I9-439; 8 (I903), 38-57, III-I26 and 29I-295; 9 (I903), 85-102.

Flors de virtut. Ed. Anna Cornagliotti, Els Nostres Clàssics A, 108. Barcelona: Editorial Barcino, 1975.

GIER, Albert, et al. Narrativa breve medieval romänica. Colección Romania, o. Granada: Ediciones TAT, I988.

El libro de Calila e Digna. Eds. John Esten Keller and Robert White Linker. Madrid: Consejo Superior de Investigaciones Científicas, 1967.

El libro de los engaños. Ed. John Esten Keller. University of North Carolina Studies in the Romance Languages and Literatures, 20. Chapel Hill: University of North Carolina Press, 1959 .

El libro de los exenplos por a.b.c. Ed. John Esten Keller. Clásicos

Hispánicos, 5. Madrid: Consejo Superior de Investigaciones Científicas, 1961 .

El libro de los gatos. Ed. John Esten Keller. Clásicos Hispánicos, 
4. Madrid: Consejo Superior de Investigaciones Científicas, 1958 .

Llull, Ramon. Llibre de les bèsties. Ed. Pere Bohigas. Antologia Catalana 1. Barcelona: Edicions 62, I965.

Miracles de la Verge Maria. Ed. Pere Bohigas. Barcelona: Biblioteca Catalana d'Obres Antigues, 1956.

MOLAS, Joaquim. Literatura catalana antiga. Vol. I: El Segle XIII. Col-lecció Popular Barcino, I93, Barcelona: Editorial Barcino, I96r.

Recull de eximplis e miracles, gestes e faules ordenades per a.b.c. Ed. M. Aguiló i Fuster. 2 vols. Barcelona: Llibreria d'Alvar Verdaguer, 1873 -1904.

Riquer, Martí de. Història de la literatura catalana, part antiga. 3 vols. Barcelona-Esplugues de Llobregat, 1964-1966. - Literatura catalana medieval. Barcelona: Ajuntament de Barcelona, 1972.

RUBió BALAgUeR, J. Literatura catalana. In vols. I and III of Historia general de las literaturas hispánicas. Barcelona, I949 and 1953 .

Ruiz i Calonja, Joan. Historia de la literatura catalana. Barcelona: Editorial Teide, I954. 